\title{
Type of Mineral Deposits on Alteration Rocks using Petrography, X-Ray Fluorescence (XRF), and X-Ray Diffraction (XRD) Method in Geothermal Prospect in Tiouw Village, Maluku
}

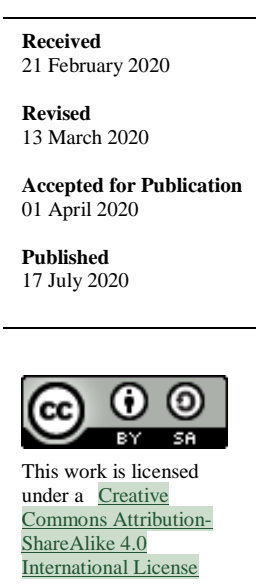

\author{
R R Lokollo ${ }^{1^{*}}$ and J R Kelibulin ${ }^{1}$ \\ 1. Physics, Faculty of Mathematics and Natural Science, Universitas Pattimura, Ir. M. Putuhena \\ Street, Ambon, 97126, Indonesia.
}

*Email: rlokollo@gmail.com

\begin{abstract}
Indonesia is a country with abundant geothermal energy potential. One of the locations that have potential geothermal energy sources is Tiouw Village, Saparua, Central Maluku. This study was conducted on the types of mineral deposits using the petrographic method, X-Ray Diffraction (XRD), and X-Ray Fluorescence (XRF). Based on the results of petrographic analysis and XRD, rock samples 1,2, and 3 of Tiouw include andesite igneous rocks with propylitic alteration type. While sample 4 is dacite igneous rock with argillic alteration type. Each rock sample has a mineral set of kaolinite, chlorite, quartz, cristobalite, epidote, and plagioclase. The XRF results showed the highest chemical composition of $\mathrm{SiO}_{2}$, followed by $\mathrm{Al}_{2} \mathrm{O}_{3}$ and $\mathrm{K}_{2} \mathrm{O}$. This mineral content can indicate the subsurface temperature of the geothermal field in the range of $200-300{ }^{\circ} \mathrm{C}$ with varying salinity, $\mathrm{pH}$ close to neutral, and low permeability. This interpreted that the type of mineral deposits in Tiouw Village was high sulfidation epithermal deposits.

Keywords: Hydrothermal alteration, petrography, XRF, XRD, rock minerals.
\end{abstract}

\section{Introduction}

Indonesia has abundant geothermal energy, such as gold, copper, platinum, nickel, lead, coal, crude oil, natural gas, and geothermal [1], [2]. Indonesia contains the largest geothermal across the world [3]. According to Geological Resource Center's (PSDG) data in 2009, there are at least 265 geothermal points in Indonesia that can be optimized as renewable energy with a potential of $28.1 \mathrm{GW}$ [4].

Geothermal is heat energy stored in subsurface rocks and fluid reserved in it as natural mineral sources found in the area of volcanic path [1]. The high temperature geothermal system associated with the volcano is divided into two, single phase geothermal system (warm water, hot water, and hot steam) and double phase geothermal system (steam domination and water domination) [5-8].

The geothermal potential of a particular area can be identified through subsurface hydrothermal alteration. Hydrothermal alteration is the texture, mineralogy, and chemical composition changes of rocks caused by hydrothermal fluid activity [9], [10]. The hydrothermal fluid is a hot liquid or fluid that raises and brings metal mineral components. This fluid is a residual solution formulated by the magma freezing process [11], [12]. Besides discovering the geothermal potential, hydrothermal alteration also identifies altered minerals and estimates fluid acidity levels [13]. The factors that affect hydrothermal alteration are temperature, pressure, permeability, chemical composition, hydrothermal composition, and side rock composition [14], [15]. A hydrothermal process on a particular balance produces groups of minerals that form mineral assemblage [16].

This study was conducted in Tiouw Village, administratively included in Central Maluku Regency, Maluku. Tiouw Village is one of the prospective geothermal areas in Maluku with geothermal manifestation, such as hot water springs and hot pool that is not yet fully developed. This research aims to identify types of hydrothermal alteration mineral deposits based on the petrological analysis of 
petrography, X-Ray Fluorescence (XRF), and X-Ray Diffraction (XRD) implemented on the surface rocks samples. According to the deposits type, the geothermal subsurface temperature (reservoir) in the research location is estimated.

\section{Method}

The research location was in hot water pool Tiouw Village (Figure 1.a), geographically located at $3^{\circ} 34^{\prime} 34.80^{\prime \prime}$ south latitude and $128^{\circ} 38^{\prime} 19.60^{\prime \prime}$ east longitude (Figure 1.b). The rock sampling technique carried out in the research location was a mesh model, as presented in Figure 2.

This research used a descriptive and analysis method based on the rocks samples in the research location. The descriptive method was carried out by identifying minerals within the rock samples. The mineral identification was completed through some techniques, microscopic, and macroscopic descriptions. From the data processing with the descriptive method, the rocks' lithology and alteration from the research location were obtained. The analysis method was carried out by correlating and analyzing the rocks' lithology and alteration data based on petrography, X-Ray Fluorescence (XRF), and X-Ray Diffraction (XRD) to obtain the conclusion on minerals characteristic of the rocks.

Petrography is part of the petrology that studies rocks' description and clarification using a polarizing microscope. The critical role of the petrographic rock description is the identification of rocks' texture, structure, and mineral composition. The petrographic analysis describes the existence of secondary mineral within the thin incision of drill cutting sample. An investigation on secondary mineral was carried out using a polarizing microscope. Additionally, X-Ray Fluorescence (XRF) analysis is a nondestructive analysis technique used to identify and determine the concentration of solid elements and the liquid sample. Contrarily, X-Ray Diffraction (XRD) analysis was conducted to identify the individual mineral [17].

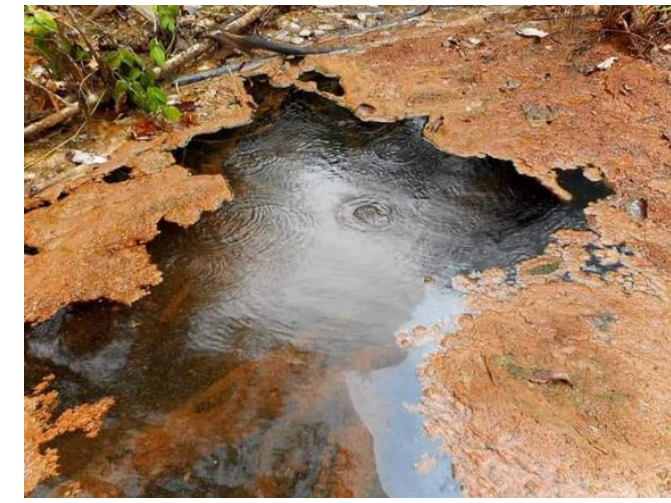

(a)

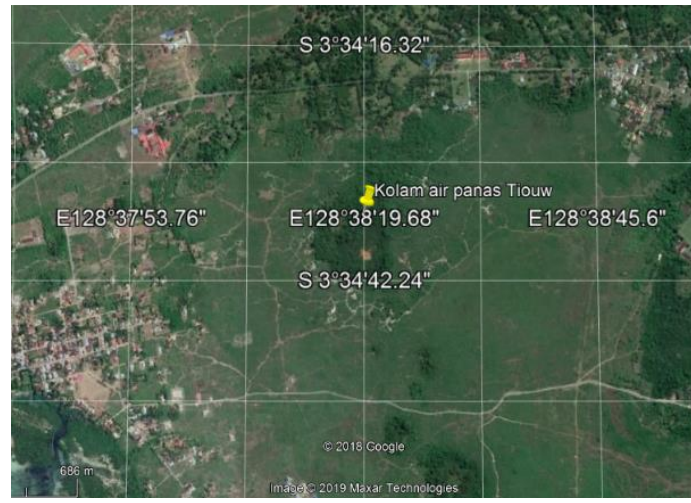

(b)

Figure 1. (a) Hot water pool in Tiouw Village, and (b) coordinate of hot springs research location in Tiouw Village.

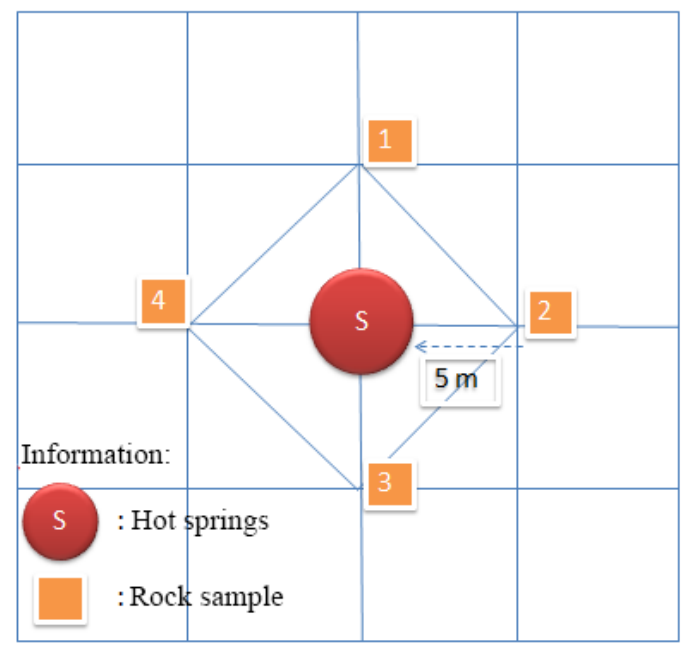

Figure 2. Sampling position with mesh model. 
At the beginning phase, the samples were chosen from all lithology unit, and their alteration type was analyzed. The alteration types based on the mineral assemblage include propylitic alteration, argillic alteration, continued argillic alteration with low temperature, continued argillic alteration with high temperature, potassic alteration, physical alteration, and silicification alteration. These alteration types were later matched with the epithermal deposits, such as high sulfidation epithermal and low sulfidation epithermal [18], [19].

\section{Result and Discussion}

\subsection{Results of Petrography Analysis}

Petrography analysis was conducted to describe the existence of secondary mineral within the thin incision of drill cutting sample. The investigation on secondary mineral was completed with a polarizing microscope.

\subsubsection{Rocks Petrology of Sample 1}

Rocks sample 1 is categorized as andesite type propylitic alteration. The altered volcanic rock incision was investigated using a polarizing microscope with ten times ocular enlargement and four times objective enlargement. Rock sample 1 has characteristics of greenish-grey with granular texture $(<0,03$ $\mathrm{mm}$ ) and embayment. The rock minerals are in the shape of euhedral-subhedral (Figure 3.a).

The composition of rocks sample 1 consists of the mineral quartz (10\%), epidote (5\%), cristobalite (5\%), chlorite (35\%), kaolinite (40\%), and opaque (5\%). The mineral quart identified has characteristics of greyish-white, refractive index $n>n K b$, low relief, with a size of $0.08-0.21 \mathrm{~mm}$, subhedral shape sized spread within the incision, and the quartz dissemination appears to be phenocryst (C2 and C6) (Figure 3.b). On the other hand, the discovered epidote mineral has the characteristics of transparent blue (D7) (Figure 3.b), high relief, $\mathrm{n}>$ balm, subhedral, BF 0.42, parallel extinction points, and appears to be phenocryst with the size of $0.23 \mathrm{~mm}$. The identified cristobalite mineral has a feature of pale grey-white (B1) (Figure 3.b), moderate relief, weak no pleochroism, anhedral-subhedral shape, and has a size of $0.25 \mathrm{~mm}$. The discovered chlorite minerals' features are yellowish-brown (B3 and C4) (Figure 3.b), moderate relief, $\mathrm{n}>\mathrm{k}-\mathrm{balm}, \mathrm{BF} 0.030$, and has a size of 0.03-0.05 mm. The kaolinite minerals' attributes involve grey white, weak relief, $\mathrm{n}>\mathrm{k}-\mathrm{balm}$, BF 0.005, appear to be the rock fundamental mass, and an observation on cross nikol position shows a dark color. Lastly, the recognized opaque minerals' characteristics are black color during the linear and cross nikol observation, isotropic, high relief has the size around $0.06-0.08 \mathrm{~mm}$, and appear to be magnetite mineral (F1 and G1) (Figure 3.b).

\subsubsection{Rocks Petrology of Sample 2}

Rocks sample 2 is classified as andesite type propylitic alteration. The altered volcanic rocks incision was studied using a polarizing microscope with ten times ocular enlargement and four times objectives enlargement. The attribute of rocks sample 2 is grey color with granular texture $(<0.3 \mathrm{~mm})$ and embayment. The rocks minerals are in the euhedral-subhedral shape (Figure 4.a).

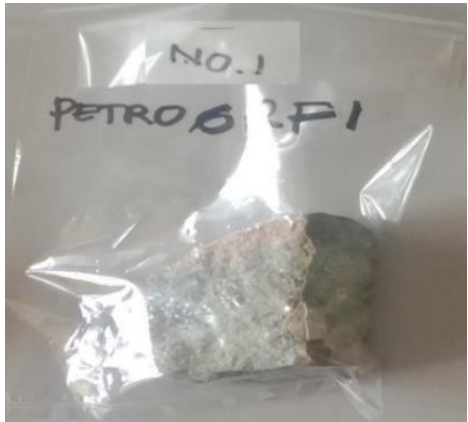

(a)

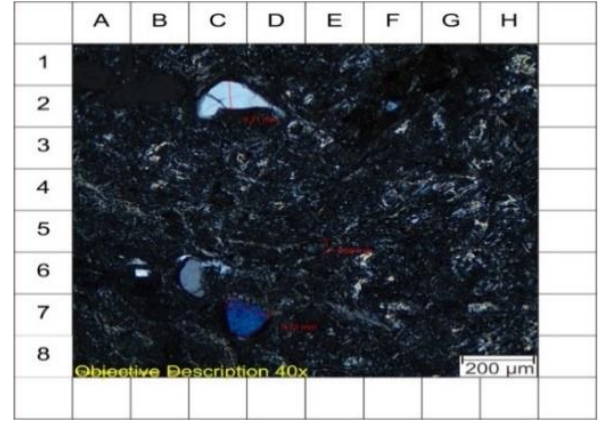

(b)

Figure 3. (a) The macroscopic of rocks sample 1, and (b) cross nikol photomicrography of rocks sample 1 (XPL). 


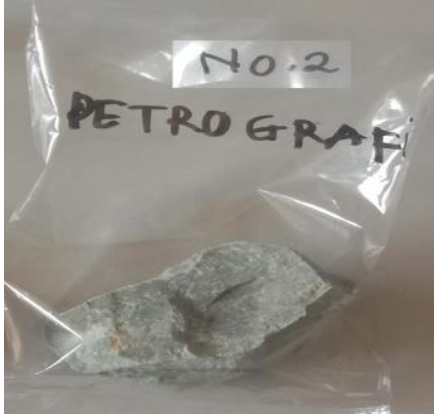

(a)

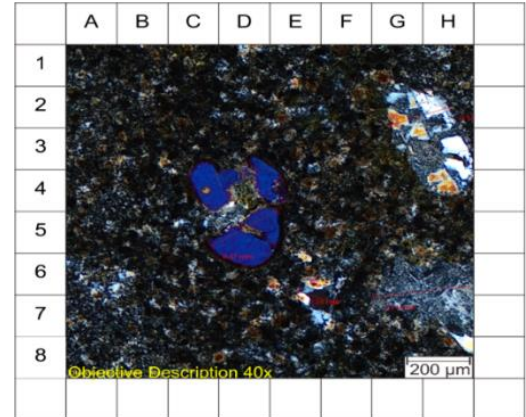

(b)

Figure 4. (a) The macroscopic of sample 2 rocks, and (b) cross nikol photomicrography of sample 2 rocks (XPL).

The rocks sample 2 consists of plagioclase (10\%), epidote (10\%), cristobalite (10\%), kaolinite $(15 \%)$, chlorite $(50 \%)$, and opaque $(5 \%)$ mineral. The found plagioclase minerals' feature involves no color $(\mathrm{H} 2-\mathrm{H} 3)$ (Figure 4.b), has a size of $0.37 \mathrm{~mm}$, a bidirectional hemisphere, moderate relief, anhedral, white grey interference color, and appears to be labradorite. The discovered epidote minerals' characteristics are transparent blue color (D4-D5) (Figure 4.b), high relief, $\mathrm{n}>$ balm, subhedral, BF 0.042 , parallel extinction points, and appears to be phenocryst with the size $0.47 \mathrm{~mm}$.

The cristobalite mineral identified in the sample has characteristics of pale grey-white (G6-H6) (Figure 4.b), moderate relief, weak no pleochroism, anhedral-subhedral shape, and the size of $0.74 \mathrm{~mm}$. The kaolinite minerals' features are white-grey, weak relief, $n>k$-balm, BF 0.005, appear to be rocks fundamental mass, and the cross nikol observation reveals a dark color. The identified chlorite minerals' characteristics are yellowish-brown, moderate relief, $\mathrm{n}>\mathrm{k}$-balm, BF 0.030, which has a size of $0.03-$ $0.05 \mathrm{~mm}$. The found opaque minerals' features include black color during the linear and cross nikol observation, isotropic, high relief, has a size of $0.03 \mathrm{~mm}$ and appears to be magnetite (B5 and C6) (Figure 4.b).

\subsubsection{Rocks Petrology of Sample 3}

The rocks sample 3 is also andesite rocks type propylitic alteration. The altered volcanic rocks incision was observed with a polarizing microscope with ten times ocular enlargement and four times objective enlargement. The rocks sample 3 features are greenish-grey with granular texture and embayment. The rocks mineral is in the euhedral-subhedral form (Figure 5.a). The rocks sample 3 composition includes quartz (30\%), hornblende (20\%), chlorite (15\%), and kaolinite (35\%) mineral. The discovered quartz minerals' characteristics of white-grey color, a refractive index of $n>n K b$, low relief, has a size of $0.03-0.17 \mathrm{~mm}$, anhedral-subhedral form extended within the incision, and the quartz is evenly spread in the incision (C7) (Figure 5.b). The identified hornblende minerals' attributes include yellowishbrown, moderate-high relief, euhedral prismatic, has the size of $0.05 \mathrm{~mm}, \mathrm{n}>\mathrm{nKb}, \mathrm{BF} 0.0019$, parallel extinction, length slow orientation, moderate double refraction order 2 (D3-D5) (Figure 5.b), and appear as phenocryst with the size of $0.39 \mathrm{~mm}$. The identified chlorite minerals' attributes are yellowishbrown, moderate relief, $\mathrm{n}>\mathrm{k}$-balm, BF 0.030, and has a size of 0.03-0.05 mm. The found kaolinite mineral has a white grey color, weak relief, $\mathrm{n}>\mathrm{k}$-balm, BF 0.005 , appear as rocks fundamental mass, and the cross nikol position observation reveals dark color.

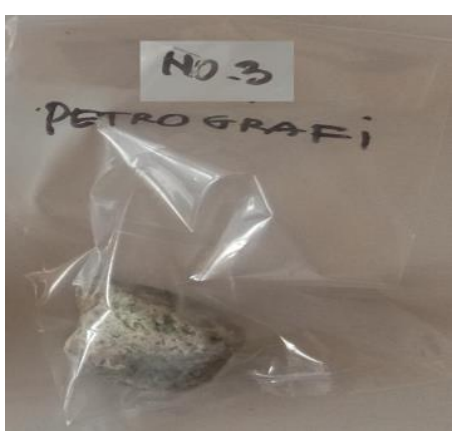

(a)

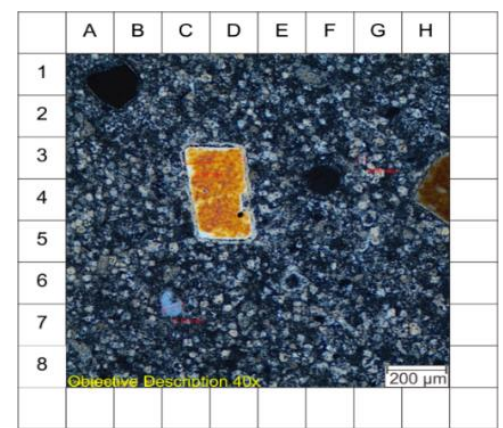

(b)

Figure 5. (a) The macroscopic of rocks sample 3, and (b) cross nikol photomicrography of rocks sample 3 (XPL). 


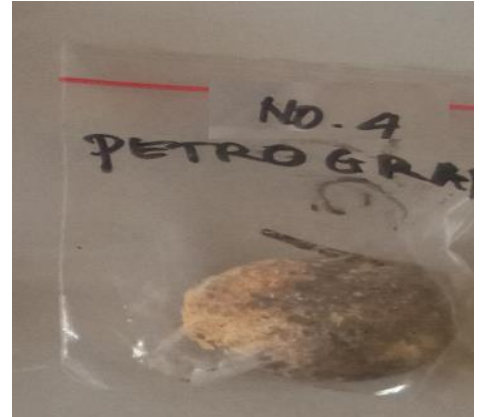

(a)

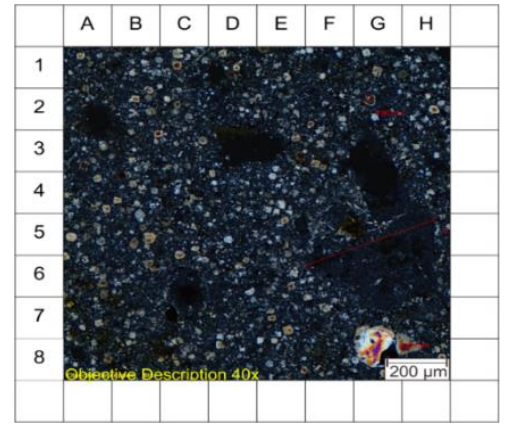

(b)

Figure 6. (a) The microscopic of rocks sample 4, and (b) cross nikol photomicrography of rocks sample 4 (XPL).

\subsubsection{Rocks Petrology of Sample 4}

Rocks sample 4 is classified as dacite rocks type argillic alteration. The altered volcanic rocks incision was investigated using a polarizing microscope with ten times ocular enlargement and four times objective enlargement. The rocks sample 4 characteristics are greenish-grey color granular texture (< $0.03 \mathrm{~mm}$ ) and embayment. The rocks mineral is in the euhedral-subhedral (Figure 6.a).

The rocks sample 4 compositions includes quartz (30\%), cristobalite (20\%), kaolinite (45\%), and opaque $(5 \%)$ mineral. The quartz mineral in it has grey-white color, refractive index $n>n K b$, low relief, size of 0.03-0.06 mm, anhedral-subhedral form disseminated across the incision, with equally spread quartz within the incision (E4) (Figure 6.b). The identified cristobalite mineral has features of pale white grey color (G5-G6) (Figure 6.b), moderate relief, weak no pleochroism, anhedral-subhedral shape, and has a size of $0.25 \mathrm{~mm}$. Besides, the identified kaolinite mineral has a white-grey color, white relief, $\mathrm{n}$ > k-balm, BF 0.005, appears to be a fundamental mass of rocks, and the cross nikol position observation reveals dark color. The found opaque mineral has black color during the linear and cross nikol observation, isotropic, high relief, the size of $0.06-0.08 \mathrm{~mm}$, and appears as magnetite (G2) (Figure 6.b).

The petrography analysis results show that rock samples 1,2, and 3 are categorized as igneous andesite with propylitic alteration type. On the other hand, rock sample 4 is igneous dacite with an argillic alteration. Generally, these two types of rock are the same. Their difference is located in their mineral size, mineral form, a secondary mineral that constitute them, and the percentage of the primary mineral. The secondary mineral is found in the rocks sample 2, meanwhile, chlorite, as a secondary mineral, is located in rocks sample 3. Additionally, the secondary mineral discovered in the rocks sample 1 and 4 is quartz mineral. These secondary minerals indicate the subsurface geothermal temperature of $200-300{ }^{\circ} \mathrm{C}$. The percentage of these secondary minerals reveals that the research location has various salinity, close to neutral $\mathrm{pH}$, and low permeability.

\subsection{Results of X-Ray Fluorescence (XRF) Analysis}

The XRF analysis results in the sample's main mineral composition, such as $\mathrm{SiO}_{2}, \mathrm{Al}_{2} \mathrm{O}_{3}, \mathrm{CaO}, \mathrm{K}_{2} \mathrm{O}$, $\mathrm{TiO}_{2}, \mathrm{~V}_{2} \mathrm{O}_{5}$, and $\mathrm{BaO}$. The minerals within each sample are presented in Table 1. Table 1 shows elements forming sediment of rocks sample 1, from the highest percentage are $\mathrm{SiO}_{2}(58.00 \%)$ and $\mathrm{CaO}$ (20.90\%). Other than those chemical compounds, $\mathrm{Al}_{2} \mathrm{O}_{3}$ of $7.85 \%$, and contains less than $5,00 \%$ other minerals, such as $\mathrm{P}_{2} \mathrm{O}_{5}, \mathrm{TiO}_{2}, \mathrm{~V}_{2} \mathrm{O}_{5}, \mathrm{Cr}_{2} \mathrm{O}_{3}, \mathrm{MnO}, \mathrm{BaO}$, and $\mathrm{Br}$. In addition, results of chemical compounds for rocks sample 2, from the highest percentage are $\mathrm{SiO}_{2}$ of $69.90 \%, \mathrm{Al}_{2} \mathrm{O}_{3}$ of $11.60 \%$, and $\mathrm{CaO}$ of $7.19 \%$. Rocks sample 2 also contains less than $5.00 \%$ other minerals, namely $\mathrm{TiO}_{2}, \mathrm{~V}_{2} \mathrm{O}_{5}, \mathrm{Cr}_{2} \mathrm{O}_{3}$, $\mathrm{MnO}, \mathrm{BaO}$, and $\mathrm{Br}$. On the other hand, the minerals composition of rocks sample 3, from the highest percentage, include $\mathrm{SiO}_{2}$ of $75.00 \%, \mathrm{Al}_{2} \mathrm{O}_{3}$ of $10.00 \%$, and $\mathrm{K}_{2} \mathrm{O}$ of $8.98 \%$. It also has less than $5.00 \%$ minerals of $\mathrm{TiO} 2, \mathrm{~V}_{2} \mathrm{O}_{5}, \mathrm{Cr}_{2} \mathrm{O}_{3}, \mathrm{MnO}, \mathrm{BaO}$, and $\mathrm{Br}$. Lastly, the minerals compositions of rocks sample 4, from the highest composition, include $\mathrm{SiO}_{2}$ of $67.10 \%, \mathrm{Al}_{2} \mathrm{O}_{3}$ of $13.60 \%$, and $\mathrm{K}_{2} \mathrm{O}$ of $8.91 \%$. The less than $5.00 \%$ minerals contained in rocks sample 4 are $\mathrm{TiO}_{2}, \mathrm{~V}_{2} \mathrm{O}_{5}, \mathrm{Cr}_{2} \mathrm{O}_{3}, \mathrm{MnO}, \mathrm{BaO}$, and $\mathrm{Br}$. 
Table 1. Compounds concentration of each rocks sample around hot water pool in Tiouw Village

\begin{tabular}{cccccccccccc}
\hline $\begin{array}{c}\text { Compounds } \\
\text { Concentration }\end{array}$ & $\begin{array}{c}\mathrm{Al}_{2} \mathrm{O}_{3} \\
(\%)\end{array}$ & $\begin{array}{c}\mathrm{SiO}_{2} \\
(\%)\end{array}$ & $\begin{array}{c}\mathrm{P}_{2} \mathrm{O}_{5} \\
(\%)\end{array}$ & $\begin{array}{c}\mathrm{K}_{2} \mathrm{O} \\
(\%)\end{array}$ & $\begin{array}{c}\mathrm{CaO} \\
(\%)\end{array}$ & $\begin{array}{c}\mathrm{TiO}_{2} \\
(\%)\end{array}$ & $\begin{array}{c}\mathrm{V}_{2} \mathrm{O}_{5} \\
(\%)\end{array}$ & $\begin{array}{c}\mathrm{Cr}_{2} \mathrm{O}_{3} \\
(\%)\end{array}$ & $\begin{array}{c}\mathrm{MnO} \\
(\%)\end{array}$ & $\begin{array}{c}\mathrm{BaO} \\
(\%)\end{array}$ & $\begin{array}{c}\mathrm{Br} \\
(\%)\end{array}$ \\
\hline Sample 1 & 7.85 & 58.00 & 0.80 & 5.08 & 20.90 & 0.31 & 0.20 & 0.74 & 4.40 & 1.70 & - \\
\hline Sample 2 & 11.60 & 69.90 & - & 5.79 & 7.19 & 0.42 & 0.24 & - & 3.00 & 1.70 & - \\
\hline Sample 3 & 10.00 & 75.00 & - & 8.98 & 2.04 & 0.26 & 0.27 & 0.61 & - & 1.60 & 0.7 \\
\hline Sample 4 & 13.60 & 67.10 & 0.87 & 8.91 & 1.84 & 0.91 & 0.28 & 0.63 & 3.00 & 2.40 & - \\
\hline
\end{tabular}

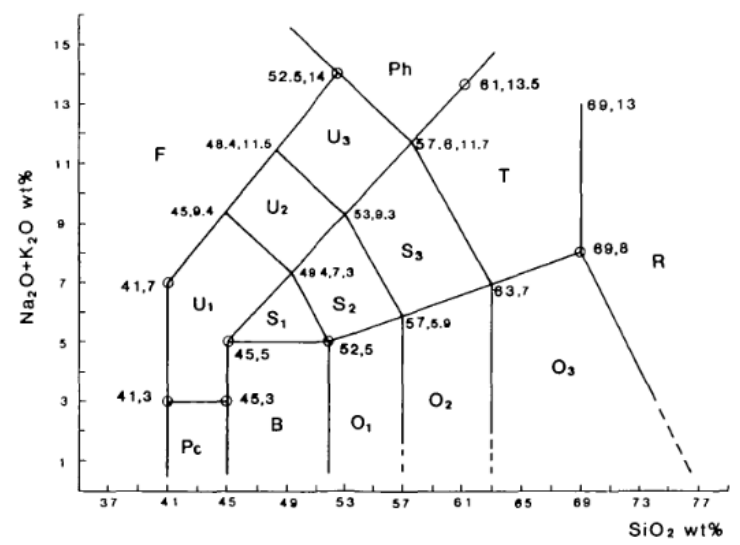

(a)

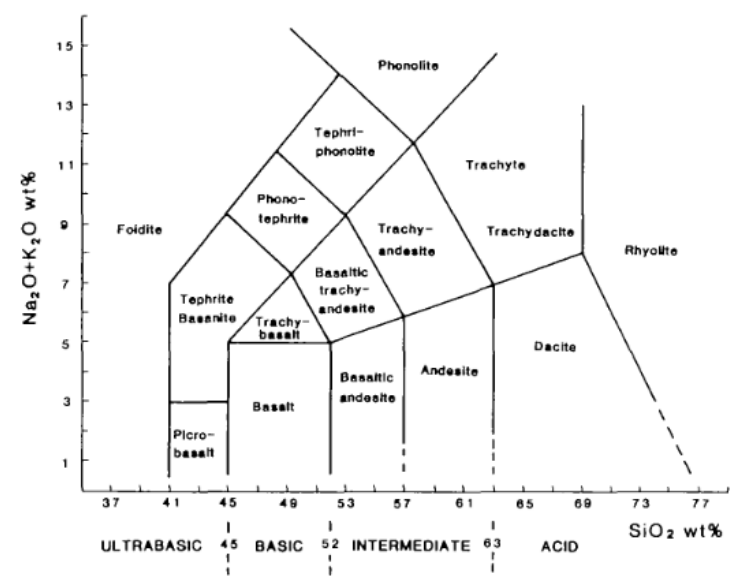

(b)

Figure 7. (a) TAS (Total Alkali-Silica) diagram representing the location and symbol of the 15 fields, along with definitive point coordinates (marked by the small circles) required to form a diagram, and (b) TAS (Total Alkali-Silica) diagram.

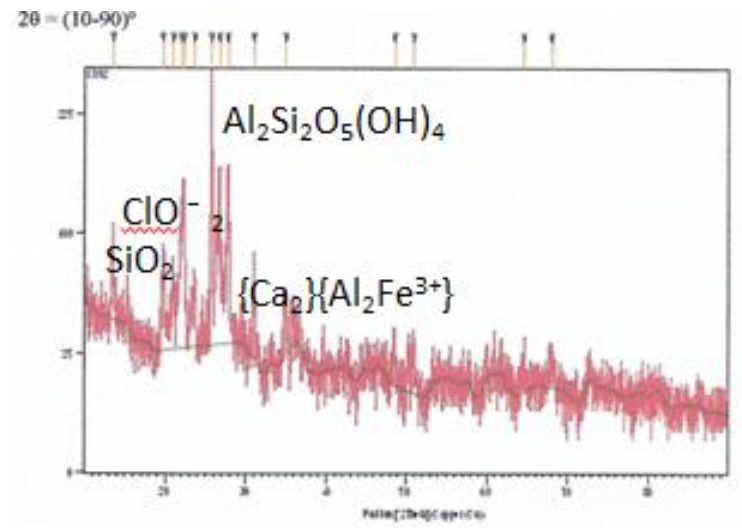

(a)

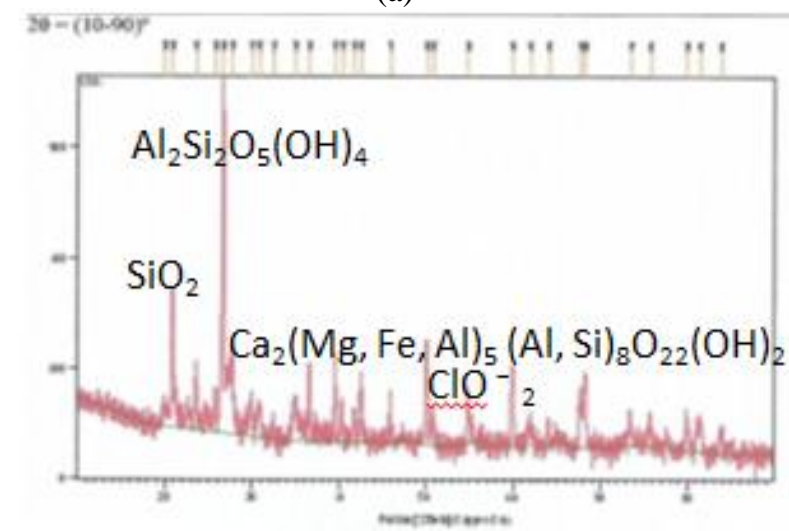

(c)

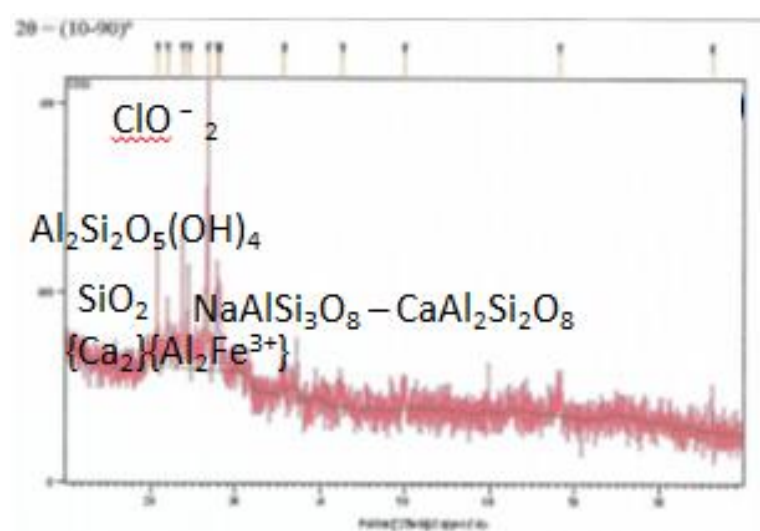

(b)

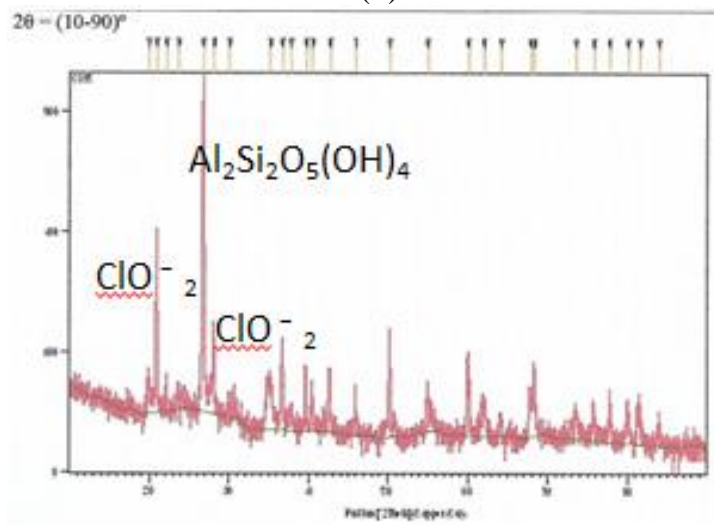

(c)

Figure 8. XRD analysis results (a) rocks sample 1, (b) rocks sample 2, (c) rocks sample 3, and (d) rocks sample 4. 


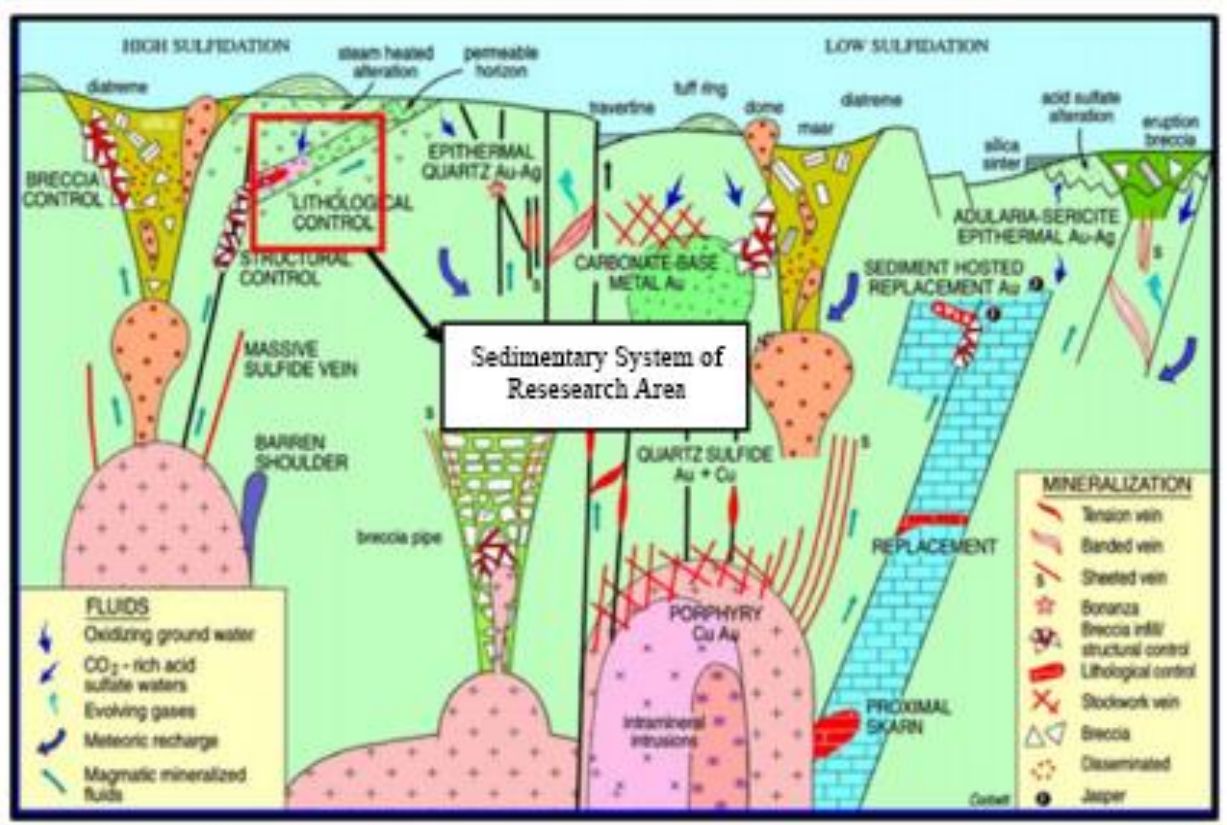

Figure 9. Epithermal deposits model.

A comparison on those minerals reveals the magma type that formulates rocks across the research location is andesite magma with moderate potassium particles that have intermediate quality. This determination is based on the total alkali-silica diagram (Figure 7) [20], [21]. Andesite rocks have a high density value of $2.4-2.8 \mathrm{~g} / \mathrm{cm}^{3}$. This high density value causes low porosity permeability value of andesite rocks.

\subsection{Results of XRD Analysis}

The XRD analysis results on those rocks samples show the dominant mineral composition of kaolinite $\left(\mathrm{Al}_{2} \mathrm{Si}_{2} \mathrm{O}_{5}(\mathrm{OH})_{4}\right)$, quartz $\left(\mathrm{SiO}_{2}\right)$, and chlorite $\left(\mathrm{ClO}^{-}\right)$. This result indicates that kaolinite mineral has the most significant percentage, on samples 1,3 , and 4 . Contrarily, rocks sample 2 is dominated by chlorite. Additionally, epidote $\left(\left(\mathrm{Ca}_{2}\right)\left(\mathrm{Al}_{2} \mathrm{Fe}^{3+}\right)\right)$ and plagioclase $\left(\mathrm{NaAlSi}_{3} \mathrm{O}_{8}-\mathrm{CaAl}_{2} \mathrm{Si}_{2} \mathrm{O}_{8}\right)$ minerals are detected at the lowest percentage, compared to other minerals, as illustrated in Figure 8.

\subsection{Deposits Type Determined from the Characteristics}

According to Corbett epithermal deposits model, the mineral features from the results of petrography, $\mathrm{XRF}$, and XRD of the rocks samples in Tiouw Village are categorized as high sulfidation epithermal deposit. It can be compared with the cross sections of high sulfidation epithermal deposits and porphyry, as illustrated in Figure 9 [14].

\section{Conclusion}

Results of petrography and X-Ray Diffraction (XRD) analysis on rocks sample 1,2, and 3 shows that rocks in Tiouw Village is classified as igneous andesite with propylitic alteration type. Meanwhile, rocks sample 4 is igneous dacite with an argillic alteration. Each rock sample has kaolinite, chlorite, quartz, cristobalite, epidote, and plagioclase mineral assemblage. Results of X-Ray Fluorescence (XRF) reveals the highest chemical compound composition of $\mathrm{SiO}_{2}\left(75.0 \%\right.$ ), then followed by $\mathrm{Al}_{2} \mathrm{O}_{3}$ and $\mathrm{K}_{2} \mathrm{O}$, respectively. These secondary minerals indicate a subsurface geothermal temperature of $200-300{ }^{\circ} \mathrm{C}$ with different salinity, close to normal $\mathrm{pH}$, and low permeability. Therefore, it can be interpreted that the mineral deposits type in Tiouw Village is high sulfidation epithermal deposits.

\section{Acknowledgment}

The most sincere gratitude is addressed to the Dean of Faculty Mathematics and Natural Science of Universitas Pattimura for the research fund year 2019 for the scope Faculty of Mathematics and Natural Science, Universitas Pattimura. 


\section{Reference}

[1] D. Gentana et al., "Alterasi Hidrotermal Gunung Rendingan Berdasarkan Analisis Petrografi dan X-Ray Diffraction (XRD),” Buletin Sumber Daya Geologi, vol. 13, no. 3, pp. 177-198, 2018.

[2] Rahmawati, S. Maryanto, and A. Susilo, "Identifikasi Sistem Panas Bumi Daerah Cangar, Jawa Timur, Menggunakan Metode Geomagnetotelurik," J. Phys. Sci. Eng., vol. 2, no. 2, pp. 72-82, 2017.

[3] S. Suryantoro et al., "Geothermal Deregulation and Energy Policy in Indonesia," in Proc. World Geothermal Congress 2005, Atalya: International Geothermal Association, pp. 1-10, 2005.

[4] Kasbani, "Sumber Daya Panas Bumi Indonesia: Status Penyelidikan, Potensi, dan Tipe Sistem Panas Bumi," in Proc. Kolokium Pusat Sumber Daya Geologi, Bandung: Kementerian Energi dan Sumber Daya Mineral, pp. 1-11, 2009.

[5] M. H. Dickson and M. Fanelli, What is Geothermal Energy?, Pisa: Istituto di Geoscienze e Georisorse, 2004.

[6] A. A. R. Zohdy, L. B. A. Anderson, and L. J. Muffler, "Resistivity Self-Potential and Induced Polarization Surveys of A Vapor-Dominated Geothermal System," Geophys., vol. 38, no. 6, pp. 1130-1144, 1973.

[7] N. C. White and J. Hedenquist, "Epithermal Gold Deposits: Styles, Characteristics, and Exploration," SEG Newslett., no. 23, pp. 1-13, 1995.

[8] F. Goff and C. J. Janik, "Geothermal Systems," in Encyclopedia of Volcanoes. H. Sigurdsson et al., Eds., Cambridge: Academic Press, pp. 817-834, 1999.

[9] M. P. Hochstein and P. R. L. Browne, "Surface Manifestation of Geothermal Systems with Volcanic Heat Sources," in Encyclopedia of Volcanoes. H. Sigurdsson et al., Eds., Cambridge: Academic Press, pp. 835-853, 1999.

[10] S. C. Creasey, "Some Phase Relation in Hydrothermally Altered Rocks of Porphyry Copper Deposits," Econ. Geol., vol. 54, no. 3, pp. 351-373, 1959.

[11] A. M. Bateman, The Fomation of Mineral Deposits, New York: Wiley, 1951.

[12] F. Pirajno, Hydrothermal Mineral Deposits, Principles and Fundamental Concepts for the Exploration Geologist, Heidelberg: Springer, 1992.

[13] V. Yosana et al., "Zona Alterasi Hidrotermal Pada Sumur Penelitian "VY 2", Lapangan Kamojang, Jawa Barat, Indonesia," Padjadjaran Geosci. J., vol. 1, no. 2, pp 164-171, 2017.

[14] G. J. Corbett and T. M. Leach, Southwest Pacific Rim Gold-Copper Systems: Structure, Alteration, and Mineralization, Colorado: Society of Economic Geologist, 1998.

[15] R. H. Silitoe, "Porphyry Copper Systems," Econ. Geol., vol. 105, no. 1, pp. 3-41, 2010.

[16] J. M. Guilbert and C. F. Park, The Geology of Ore Deposits, Illinois: Waveland Press, 1986.

[17] A. M. Evans, Ore Geology and Industrial Minerals, 3rd ed., Oxford: Blackwell Science, 1993.

[18] D. A. John et al., "Descriptive Models for Epithermal Gold-Silver Deposits," USGS: United States of America, Rep. 2010-5070-Q, 2018.

[19] H. V. Mcgregor and M. K. Gagan, "Diagenesis and Geochemistry of Porites Corals from Papua New Guinea: Implications for Paleoclimate Reconstruction," Geochimica et Cosmochimica Acta, vol. 67, no. 12, pp. 2147-2156, 2003.

[20] M. J. L. Bas et al., "A Chemical Classification of Volcanic Rocks Based on the Total AlkaliSilica Diagram," J. Petrol., vol. 27, no. 3, pp. 745-750, 1986.

[21] R. W. L. Maitre, Igneous Rocks: A Classification and Glossary of Terms, 2nd ed., New York: Cambridge University Press, 2002. 